\title{
Asset Holdings of Young Households: Trends and Patterns
}

\author{
Ellen A. Merry and Logan Thomas
}

\begin{abstract}
The authors use multiple waves of the triennial Survey of Consumer Finances (SCF) from 1989 to 2013 to examine the composition of the asset portfolios of young households whose head of household is between 18 and 41 years of age. The focus is on households' decisions to hold different types of assets, including both financial assets (e.g., bank accounts, stocks, and retirement accounts) and nonfinancial assets (e.g., residential real estate, businesses, and automobiles). The authors describe the patterns of acquisition of broad asset categories in the early part of the life cycle with attention to patterns that appear to have changed over time and explore how the propensity to hold different types of assets varies across households. (JEL D14, D31, G11)
\end{abstract}

Federal Reserve Bank of St. Louis Review, Fourth Quarter 2014, 96(4), pp. 391-411.

$\mathbf{R}$ ecent research focused on how young households fared throughout the Great Recession has highlighted the losses this group incurred, in part because a large share of their assets was in housing. Emmons and Noeth (2013) find evidence that homeownership rates in 2007 were elevated for younger households relative to earlier years after controlling for other factors. The significant losses in wealth as a result of the Great Recession have prompted many questions about how households, particularly younger households and minorities, can rebuild and invest for the future.

This article builds on the existing work on portfolio choices of young households and focuses on households' decisions to hold a range of asset types, including both financial assets (e.g., bank accounts, stocks, and retirement accounts) and nonfinancial assets (e.g., residential real estate, businesses, and automobiles). While several recent articles on the 2007-09 recession and recovery have focused on the losses and gains experienced by different groups, including the young, the possible changes in household decisions to hold different types of nonhousing assets in recent years have received less attention. The composition of asset ownership is important for both long-term economic mobility and the ability of households to weather temporary

Ellen A. Merry is a senior economist and Logan Thomas is a research assistant in the Division of Consumer and Community Affairs of the Board of Governors of the Federal Reserve System. The authors thank Arthur Kennickell, Kevin Moore, Trina Williams Shanks, and colleagues in the Board's Division of Consumer and Community Affairs for their comments and suggestions. This article was prepared for the symposium "The Balance Sheets of Younger Americans: Is the American Dream at Risk?" presented May 8 and 9, 2014, by the Center for Household Financial Stability and the Research Division at the Federal Reserve Bank of St. Louis and the Center for Social Development at Washington University in St. Louis.

(c) 2014, The Federal Reserve Bank of St. Louis. The views expressed in this article are those of the author(s) and do not necessarily reflect the views of the Federal Reserve System, the Board of Governors, or the regional Federal Reserve Banks. Articles may be reprinted, reproduced, published, distributed, displayed, and transmitted in their entirety if copyright notice, author name(s), and full citation are included. Abstracts, synopses, and other derivative works may be made only with prior written permission of the Federal Reserve Bank of St. Louis. 


\section{Merry and Thomas}

financial shocks. For example, stocks have historically provided a greater return over time but also involve a greater risk of loss over shorter time horizons. In contrast, bank accounts grow more slowly over time but offer a ready reserve for emergencies. Recent decades provide examples of both positive and negative impacts of asset price changes on household balance sheets depending on the degree of exposure to different asset classes.

We use the triennial Survey of Consumer Finances (SCF) to examine the composition of the asset portfolios of young households whose head of household is between 18 and 41 years of age over the years 1989 to 2013. While the SCF does not follow the same households over this entire period, it does allow us to study different cohorts or groups of young adults who entered adulthood at different points in time. The next two sections describe the asset categories used in the analysis and the young adults included in the measures of asset ownership constructed with the SCF data. We then describe the patterns of acquisition of broad asset categories in the early part of the life cycle with attention to patterns that appear to have changed over time and explore how the propensity to hold different types of assets varies across households.

\section{DATA AND DESCRIPTIONS OF ASSET CATEGORIES}

This article uses data from the Federal Reserve Board's SCF collected from 1989 through 2013 to examine the composition of household assets. The SCF is a triennial cross-sectional survey of households that includes detailed information on assets, liabilities, and income as well as attitudes toward saving, credit, and risk. The SCF uses a two-part sampling frame and oversamples wealthy households in an effort to measure the wealth holdings concentrated among households at the top of the wealth distribution. As Kennickell (2009) notes, since 1989 the SCF has been conducted using comparable methodologies that facilitate comparisons over time. ${ }^{1}$

The SCF measures both assets and liabilities. Although not provided here, a complete treatment of asset ownership would involve examining the relationship between the use of debt—particularly secured debt—and asset holdings. Much recent work on household balance sheets has focused on the role of home leverage and its implications for households' ability to enter, sustain, and benefit financially from homeownership. ${ }^{2}$ Other assets, such as businesses and vehicles, are also often financed by loans.

As a complement to this literature on the distribution of and changes in net worth, our focus here is on the composition of household assets to better understand which households are exposed to the potential financial risks and rewards that accompany the decision to allocate wealth to a particular asset type. For assets that may have associated secured debt, we focus on the ownership of the asset, not the value, for two reasons. First, assets may yield service flows or income (in the case of a business) even if their net equity value is zero or negative. ${ }^{3}$ Second, we are interested in exposure to the potential risks and rewards of asset ownership over the longer term, not necessarily the value of the asset if it were liquidated at the time of the survey. Negative net equity positions in assets can be a serious concern for household financial security and can be associated with bankruptcy, foreclosure, and other types of 


\section{Table 1}

\section{Asset Categories}

\begin{tabular}{|c|c|}
\hline Broad asset category & Assets included \\
\hline Transaction accounts and CDs & $\begin{array}{l}\text { Checking, savings, and money market deposit accounts; money market } \\
\text { mutual fund and call accounts; CDs }\end{array}$ \\
\hline Vehicles & Autos, motor homes, recreational vehicles, airplanes, or boats \\
\hline Residential real estate & Owner-occupied or other residential real estate \\
\hline Retirement accounts & $\begin{array}{l}\text { Quasi-liquid retirement accounts, including IRAs and Keogh, thrift, } \\
401(\mathrm{k}), 403(\mathrm{~b}) \text {, and supplemental retirement accounts }\end{array}$ \\
\hline Bonds, stocks, and mutual funds & $\begin{array}{l}\text { Bonds (including savings bonds), stocks, and non-money market mutual } \\
\text { funds }\end{array}$ \\
\hline Business equity and nonresidential real estate & Business equity or nonresidential real estate \\
\hline Other assets & $\begin{array}{l}\text { Cash value of life insurance, other managed assets (e.g., trusts, annuities), } \\
\text { and other financial or nonfinancial assets }\end{array}$ \\
\hline
\end{tabular}

financial distress. However, the focus on ownership here is intended to be a complement to, not a substitute for, other work focused on values and net worth.

While the SCF includes very detailed information on many types of assets, for the purpose of this study, assets are grouped into several broad categories. This aggregation approach is similar to that used by Gouskova, Juster, and Stafford (2006) in their analysis of household portfolios using the Panel Study of Income Dynamics. The seven categories and the component asset types that comprise each one are listed in Table 1 and discussed below.

\section{Transaction Accounts and CDs}

Following Bricker et al. (2012), the category for transaction accounts is composed of checking, savings, and money market deposit accounts plus money market mutual funds and cash or call accounts at brokerage firms. In addition to transaction accounts, certificates of deposit (CDs) are also included in this category. Transaction accounts are characterized by the immediate availability of their funds and generally stable asset values. Although CDs may be subject to early withdrawal penalties, they are not subject to the fluctuations in value that occur with some other financial assets such as bonds, stocks, and non-money market mutual funds. These characteristics of liquidity, immediate (or rapid) availability of funds, and stability of asset values make these financial products readily accessible. However, the lack of exposure to market fluctuations implies that these assets yield a lower rate of return than some riskier assets. The lower return raises the likelihood that the real rate of return for households with transactions accounts and CDs may be negative over some periods if the nominal after-tax rate of return is lower than the inflation rate.

\section{Vehicles}

For most SCF respondents, the vehicles asset category reflects ownership of an automobile. However, this asset category also includes motor homes, recreational vehicles, airplanes, and 


\section{Merry and Thomas}

boats. Unlike many of the other asset categories, vehicles typically offer little opportunity for appreciation in the value of the asset over time unless they are vintage or collectible models. Although automobiles may be a poor store of value based on their likely depreciation and need for upkeep, they can have important impacts on financial security and economic opportunity beyond the market value reflected on the household balance sheet. For example, Pendell et al. (2014) find that automobile access has effects on the economic opportunities available to housing voucher recipients.

Wolff (2006) excludes automobiles, appliances, and other consumer durables from household wealth, noting that such assets may be more valuable for their service flow than as a source of potential funds were they to be sold. However, Kennickell (2009) notes that vehicles are a particularly important component of wealth for low-income and low-wealth groups and that other assets - particularly owner-occupied housing - also yield a flow of services. Many young adults have low wealth or low income as they enter adulthood; therefore, including vehicles would seem important for a study of asset holdings of this population.

\section{Residential Real Estate}

The residential real estate category includes both owner-occupied homes and other residential real estate. These other residential properties could include second or vacation homes and any properties that may be used as rental properties for additional income. For all SCF waves used in this study, almost all households who own residential real estate own their homes. While some respondents do own other residential real estate in addition to their home, only 1 to 2 percent of young households own other residential real estate without also owning their home.

\section{Retirement Accounts}

The retirement accounts category includes tax-deferred retirement accounts such as individual retirement accounts (IRAs), Keogh, thrift, 401(k), 403(b), and supplemental retirement accounts. ${ }^{4}$ The underlying assets in these accounts vary and include stocks, bonds, and mutual funds. However, because institutional factors can play such a significant role in the acquisition of assets in retirement accounts, they are treated as a distinct category. Employer-sponsored plans such as $401(\mathrm{k})$ s may have features that may include automatic payroll deductions, matching, and automatic enrollment that encourage employees to enroll and contribute a portion of their salary to saving in the plan. IRA owners may have more latitude than participants in $401(\mathrm{k}) \mathrm{s}$ or other employer-sponsored plans to choose the fund company and asset allocation. However, Holden and Bass (2014) find that few investors in traditional IRAs contribute to these plans, and most new traditional IRA accounts are created with rollovers from employersponsored plans. Thus, access to and participation in employer-sponsored retirement plans can have a significant impact on whether households have assets in various types of retirement accounts.

\section{Bonds, Stocks, and Mutual Funds}

While many households who hold bonds and stocks do so in tax-deferred retirement accounts, some households hold these assets directly. Holdings of these assets outside retire- 
ment accounts are captured in the bonds, stocks, and mutual funds category. This asset category includes U.S. savings bonds, municipal and corporate bonds, directly held stocks, and non-money market mutual funds held outside a retirement account.

\section{Business Equity and Nonresidential Real Estate}

Following Bricker et al. (2012), business equity in the SCF reflects the ownership of a range of business types, including sole proprietorships, partnerships, and privately held corporations. Nonresidential real estate includes commercial properties, residential structures with more than five units, and undeveloped land. Farm and ranch land, as well as assets associated with agricultural businesses, are also included in this category. Bricker et al. (2012) also note that because nonresidential real estate investments may have multiple owners and may be highvalue investments associated with large mortgages that are paid out of the income from the property, these assets may more closely resemble a business than residential investment properties. For this reason, ownership of privately held businesses and nonresidential real estate is grouped together into a single asset category for our analysis.

The summary data extracts of SCF data used here compute the value of business equity and nonresidential real estate net of any associated debt. Although most households who hold these assets have positive net equity in them, for some asset holders these categories have negative or zero net asset values. As noted previously, we use a measure of ownership of the asset, not its value, so households with no net equity in the business are still included as owning assets in this category.

\section{Other Assets}

The remaining category of "other assets" includes all other financial assets, such as the cash value of life insurance policies, deferred compensation, and trusts, plus all other nonfinancial assets, such as jewelry, artwork, and various collections (e.g., baseball cards, records, and wine).

While the SCF provides detailed information on the broad range of asset types listed above, some sources of wealth are not included. Kennickell (2009) notes that the SCF does not measure, or provides only limited information on, particular forms of wealth. ${ }^{5}$ For example, the survey includes questions about whether members of the household are covered by a pension plan, but the value of defined benefit pensions is not measured. Similarly, educational attainment is included, but the value of human capital is not measured. Even though the asset categories included here may be incomplete, they nonetheless reflect many of the major stores of wealth for households across the wealth distribution.

\section{YOUNG HOUSEHOLDS IN THE SCF}

In the following descriptions of asset holding, a portion of the young adult population is reflected in the asset measures provided by the SCF and a portion may be missing because of the survey design. Dettling and Hsu (2014) note that the SCF's design captures the asset holdings of young adults who have formed independent households but is not well suited for 


\section{Merry and Thomas}

studying the balance sheets of young adults living with parents or roommates. When young adults are still included in their parents' household, their asset information may be collected but cannot be separately identified. Asset data for those living with roommates are collected only for the head of the household, who is defined as the oldest member of the household. Thus, the asset measures for young households presented in this article reflect only the holdings of independent households in which the head is between 18 years of age and their early 40s. This includes married, cohabitating, and single-person households, as well as some heads of household who may live with younger roommates not captured in the survey.

The lack of information on asset ownership for young adults not living in independent households may affect profiles of asset acquisition for several reasons. First, the characteristics and asset ownership patterns of young adults who form independent households may differ from those living with parents or roommates. Dettling and Hsu (2014) compare median wage income measures for young adults (18 to 31 years of age) in the Census Bureau's Current Population Survey (CPS) with estimates of wage income for individual young adults in the SCF and find that this income measure in the SCF is higher by around $\$ 10,000$ over the 2001-10 period. This finding may suggest that the young adult households included in the SCF may be doing better on average than young adults living with parents or roommates who are not included in the SCF.

Second, if household formation patterns change, then the households reporting asset holdings will change, potentially altering the composition of the sampled population. Dettling and Hsu (2014) note that household formation patterns have changed since 2001: Young adults 18 to 31 years of age are more likely to be living with parents in more recent years. However, they also examine the wage data previously mentioned and find that the $\$ 10,000$ difference in wage income between young adults in the CPS and SCF has been relatively stable over time. This could imply that even with the recent changes in household formation, the composition of the underlying population of independent households has not necessarily changed markedly.

Finally, the characteristics of young adults may differ based on the age at which they form independent households. If so, profiles of asset acquisition reflect both changes in the likelihood of owning assets as people age and changes in the composition of the households we observe. For example, young adults who attend college may be less likely to be sampled when they are 18 to 23 years of age as they may still be dependent on their parents. Once they graduate and are employed, they may form households. College graduates may be more likely to have access to and participate in retirement savings plans at work than the population that did not attend college. This could imply that our observed increase in ownership of retirement accounts between the 18- to 23-year age group and the 24- to 29-year age group is affected by the entry into the sample of households who are more likely to own retirement accounts, and not just an increase in ownership of retirement assets with age.

Because we are not able to track individual households over time in the SCF, we cannot distinguish the "newly formed" households from those who formed households at earlier ages. Thus, the profile of asset ownership should be interpreted as a series of snapshots of young households that can be observed over time, recognizing that the snapshots reflect an increasing share of the young adult population as it ages and that the composition of the observed groups may be changing across time. 


\section{Figure 1}

\section{Ownership of All Asset Categories: All Ages 18-41 Years}

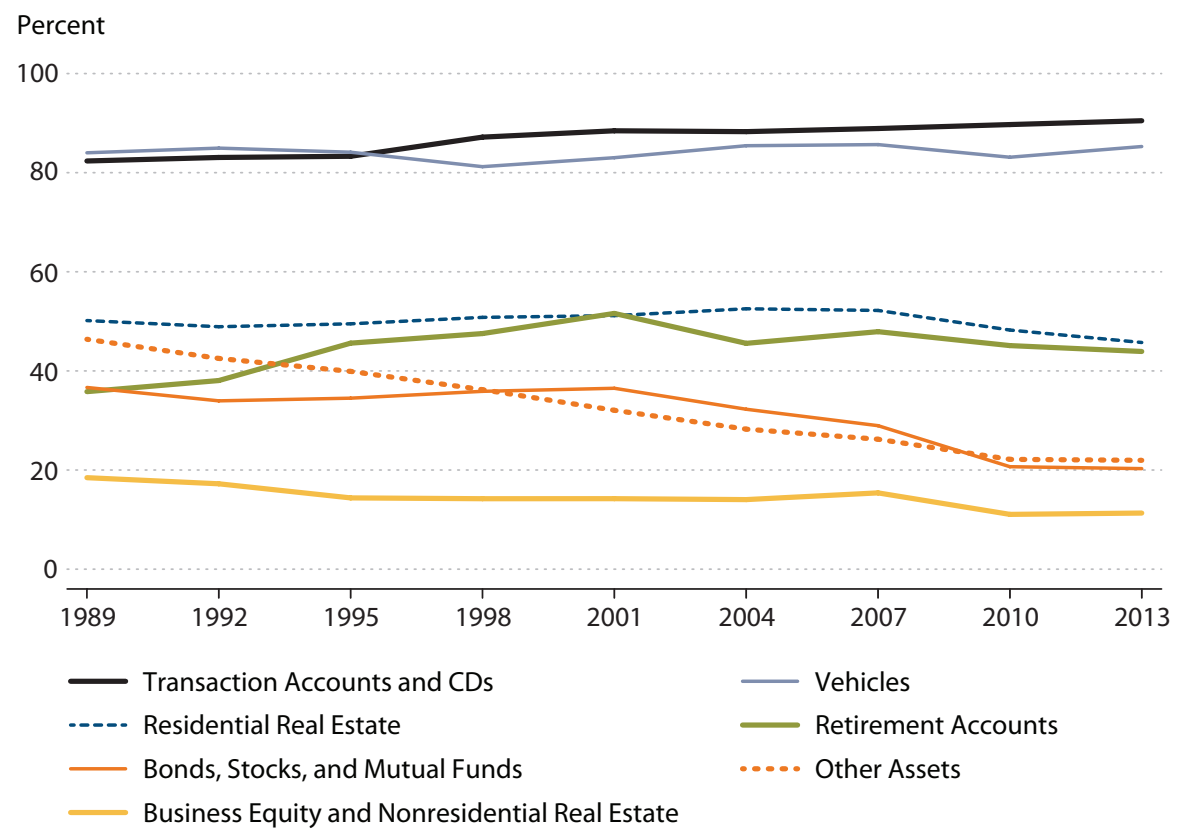

SOURCE: SCF.

\section{OVERVIEW OF TRENDS AND PATTERNS IN ASSET HOLDINGS}

We first examine ownership of each asset category, where we see wide differences in the incidence of ownership between asset types and some indications of changes over time. Figure 1 shows ownership of the various asset categories from 1989 through 2013 for households whose head is between 18 and 41 years of age. ${ }^{6,7}$

Two categories - transaction accounts and CDs and vehicles-have the highest ownership rates over all waves of the SCF. Figure 1 clearly shows that these two assets are the most commonly held asset categories among those 18 to 41 years of age. Ownership of transaction accounts and CDs exceeded 80 percent for this entire period, trending up from 82 percent in 1989 to around 90 percent in 2013. Vehicle ownership also was above 80 percent over this time, registering between 83 and 86 percent with a dip to 81 percent in 1998. Ownership of vehicles also declined a bit between 2007 and 2010 before increasing again in the 2013 survey.

Residential real estate is the third most commonly held asset type; ownership rates for young households hovered around 50 percent over most of this period. Ownership rates in 2004 and 2007 were around 52 percent but declined to 48 percent in 2010 and 46 percent in 2013.

Ownership of retirement accounts increased from 36 percent in 1989 to around 52 percent in 2001. Ownership has dropped a bit in more recent years. In 2013, 44 percent of young households had assets in this fourth most common asset category. 
Table 2

Six-Year Age Cohorts

\begin{tabular}{lcc} 
Birth years & $\begin{array}{c}\text { Year cohort was } \\
\mathbf{1 8 - 2 3} \text { years of age }\end{array}$ & $\begin{array}{c}\text { SCF waves when cohort was } \\
\mathbf{1 8 - 4 1} \text { years of age (44) }\end{array}$ \\
\hline $1948-53$ & 1971 & $1989(1992)$ \\
$1954-59$ & 1977 & $1989-95(1998)$ \\
$1960-65$ & 1983 & $1989-2001(2004)$ \\
$1966-71$ & 1989 & $1989-2007(2010)$ \\
$1972-77$ & 1995 & $1995-2013$ \\
$1978-83$ & 2001 & $2001-13$ \\
$1984-89$ & 2007 & $2007-13$ \\
$1990-95$ & 2013 & 2013
\end{tabular}

NOTE: Ownership rates for the four older cohorts are also included for years when the head was between 39 and 44 years of age, as noted in parentheses.

Ownership of the three less widely held asset categories declined over this period. Ownership rates for the bonds, stocks, and mutual funds category ranged from 34 to 37 percent from 1989 to 2001 but declined in more recent years to around 20 percent in 2013. Ownership of other assets declined as well, falling steadily from 46 percent in 1989 to 22 percent in 2013. Business equity and nonresidential real estate, now the least commonly held asset category, also registered a decline in ownership rates: from 18 percent of young households in 1989 to 15 percent in 2007 and 11 percent in 2013.

\section{Ownership Over the Life Cycle}

We construct cohorts based on the years that respondents enter adulthood to examine life cycle patterns of ownership. While we cannot follow the same households over time, we are able to follow the cohorts over time as samples in each successive SCF are weighted to be representative of the underlying population of young households. Using 6-year age groupings, we compute asset ownership rates for eight cohorts in the 18- to 41-year age range during one or more waves of the SCF between 1989 and 2013 (Table 2). In the accompanying figures, cohorts are identified by the year in which the members of that cohort were 18 to 23 years of age. The oldest cohort observed during ages 18 to 41 is the group of young adults who were between 36 and 41 years of age in 1989; the youngest cohort appears initially in the 2013 survey. Two cohorts-those 18 to 23 years of age in 1989 and those 18 to 23 years of age in 1995-can be followed throughout their early adult years in the triennial SCF surveys.

Because the cohorts are defined by 6-year groupings of birth years, we defined 6-year age groups of young adults (18-23, 24-29, 30-35, and 36-41 years) to follow them through their early adult years. The labeled tick marks on the figures reflect the ages of the cohorts in the $1989,1995,2001,2007$, and 2013 waves of the SCF. Since the SCF is collected every three years, cohorts "age into" the next age group every other wave of the SCF. The unlabeled tick marks 
reflect measures for that cohort from the other waves of the SCF $(1992,1998,2004$, and 2010) when the cohort was between two age groups. For example, those in the 18- to 23-year group in 1989 were between 21 and 26 years of age in 1992 and between 24 and 29 years of age in 1995. The individual lines follow the same cohort over time through the various waves of the SCF as the cohort ages. While our focus is on households in the 18- to 41 -year age range, we include observations for cohorts who are 39 to 44 years of age in 1992, 1998, 2004, and 2010. While this extends the age range slightly, it also allows us to observe the changes in ownership from 2007 to 2010 for all cohorts observed in 2007. This period is noteworthy as it captures changes to household balance sheets that may have occurred around the Great Recession.

Figure 2 shows asset ownership profiles for all cohorts across the seven asset categories. Ownership rates for transaction accounts and CDs are relatively high even for the youngest households in the SCF and increase over the early part of the adult life cycle (Figure 2A). For all cohorts observed in their 20s, ownership rates for this asset category are above 65 percent for households 18 to 23 years of age and climb above 80 percent by the time they reach their late 20s. Increases in ownership as households age into their 30 s and early 40 s are smaller, with ownership rates around 85 to just above 90 percent by the late 30 s or early 40 s.

As with ownership of transaction accounts, vehicle ownership is relatively high for very young adults (Figure 2B). Around 65 to 75 percent of those in the 18- to 23-year age group own vehicles; this proportion increases to around 85 or 90 percent by the early to mid-30s.

Ownership patterns for residential real estate follow a distinct pattern of acquisition over the early adult life cycle (Figure 2C). Rates of ownership increase substantially from the earliest age group to the oldest: from between 10 and 20 percent for the 18- to 23-year age group to 60 to 75 percent by the early 40 s.

As with real estate, ownership of retirement accounts rises steadily over the early adult life cycle (Figure 2D). Rates of ownership are low early-around 20 percent or below for those 18 to 23 years of age-but increase to about 50 to 60 percent by the mid-30s and early 40s.

While a sizable share of young adult households have acquired transaction accounts, vehicles, homes, and retirement accounts by the time they reach their 40s, ownership of the remaining three asset types is less prevalent across this population. Ownership rates of bonds, stocks, and mutual funds also trend upward as households move through the early adult portion of the life cycle, although ownership rates have dropped off noticeably in recent years (Figure 2E).

Ownership of business equity and nonresidential real estate increases with age, although even by the late 30 s or early 40s, ownership rates are lower than the other six asset categories (Figure 2F).

Ownership rates for the other assets category decline between the older cohorts and the younger ones (Figure $2 \mathrm{G}$ ). This declining trend in ownership over time is the dominant pattern in the holdings of other assets for young households, and thus Figure $2 \mathrm{G}$ does not indicate any particular life cycle profile of acquisition.

\section{Changes in Ownership Patterns Over Time}

While Figure 2 follows particular cohorts as they age, the remaining figures focus on the patterns for particular age groups across all nine waves of the SCF from 1989 to 2013. Owner- 


\section{Merry and Thomas}

\section{Figure 2}

\section{Asset Ownership Over the Young Adult Life Cycle}
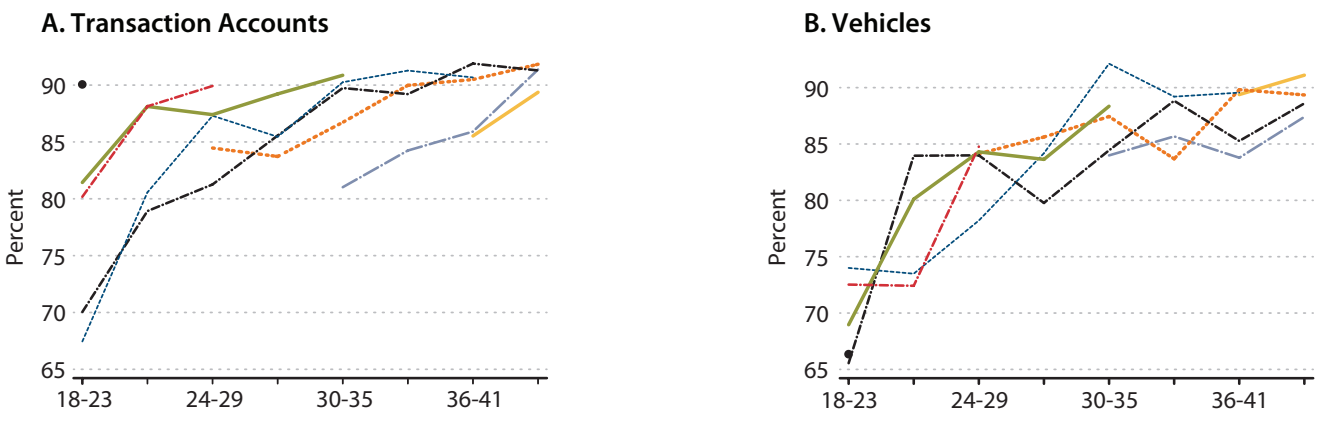

\section{Residential Real Estate}

\section{Retirement Accounts}

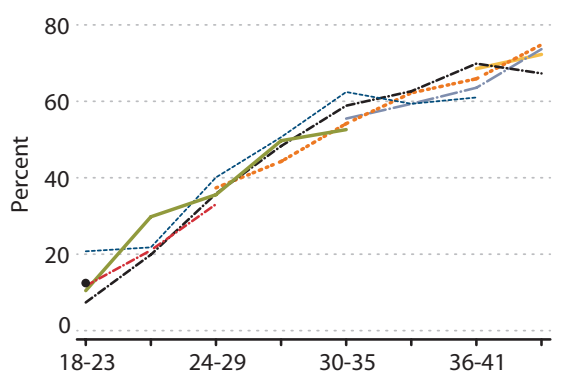

E. Bonds, Stocks, and Mutual Funds
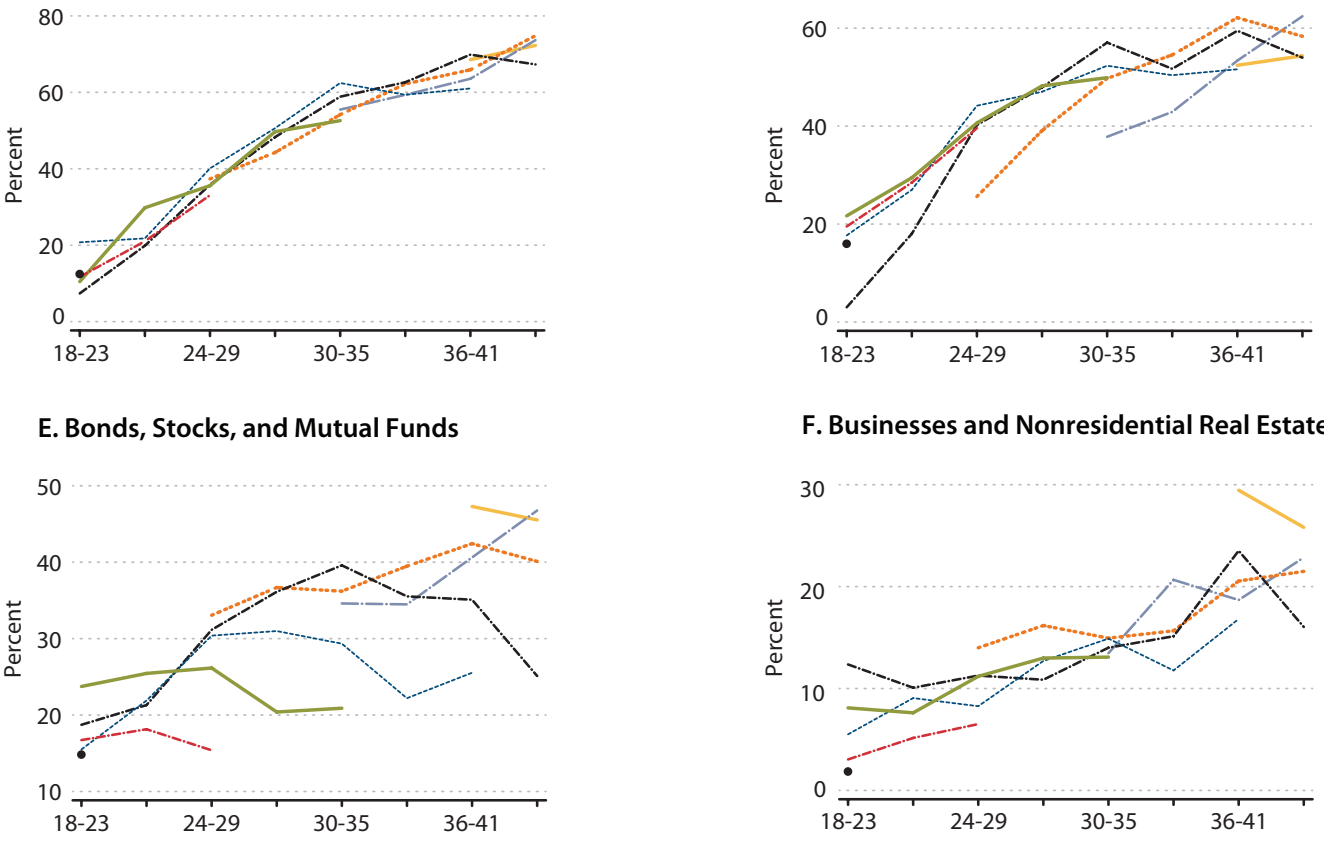

F. Businesses and Nonresidential Real Estate

30

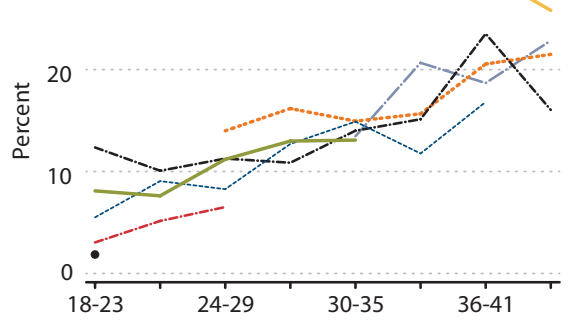

G. Other Assets

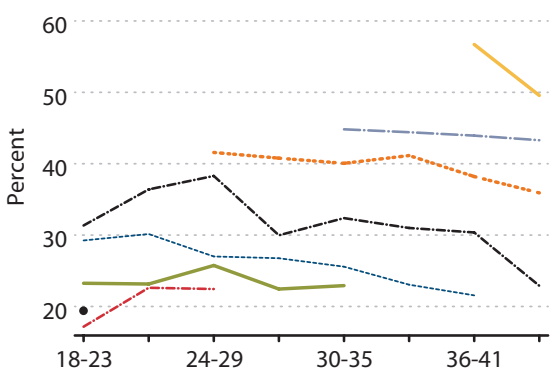

Age Cohorts

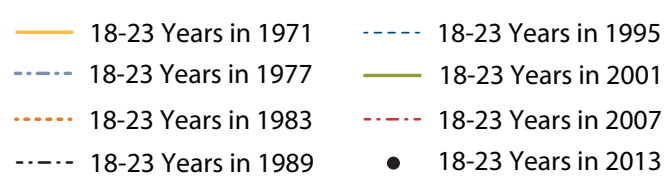

SOURCE: SCF. 


\section{Figure 3}

\section{Ownership of Transaction Accounts and CDs}

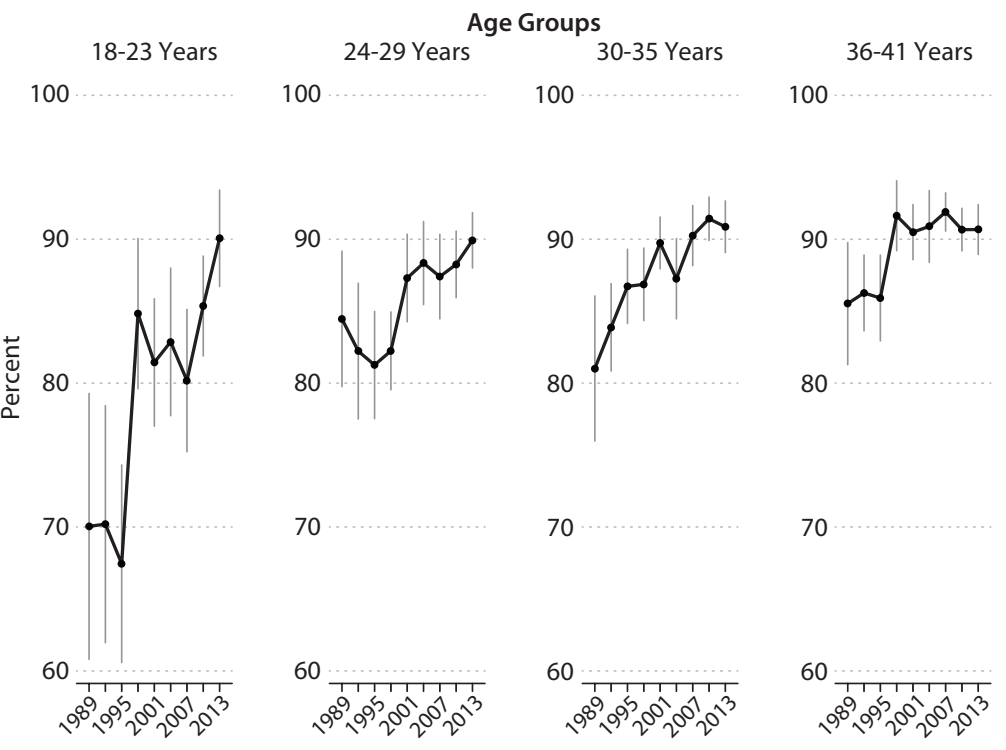

NOTE: Vertical bars represent 95 percent confidence intervals for the means of the groups.

SOURCE: SCF.

ship of transaction accounts and CDs increased across all four age groups, but the increase was most pronounced for those in the 18- to 23-year age group (Figure 3)..$^{8,9}$ This rise in ownership and earlier acquisition of transaction accounts and CDs may be related to the increased use of direct deposit over time, whereby employees are required to have some type of transaction account. Hogarth, Anguelov, and Lee (2005) note that changes in government policy, such as the move to electronic benefits transfers, may have increased ownership of transaction accounts, and they document the increase in account ownership over time in the broader population as well.

Vehicle ownership rates show some differences over time (Figure 4). Mannering, Winston, and Starkey (2002) document the rise in consumer auto leasing over the 1990s. The SCF data on vehicle leasing (not shown) show a sharp rise in the share of households with leased vehicles between 1992 and 1998. This share remained elevated into the early 2000s, so leasing may have contributed to the estimates showing a lower propensity to own vehicles for some age groups during this period. While strong trends are not evident in the pattern of vehicle acquisition between the earlier and later years, vehicle ownership rates are lower for the 18- to 23-year age group in recent waves of the SCF.

Ownership rates for residential real estate have remained generally consistent over time for the younger age groups in their 20s (Figure 5). Ownership rates climb markedly for young households in their 30s and early 40s. Therefore, it is not surprising that the impact of the 


\section{Figure 4}

\section{Ownership of Vehicles}

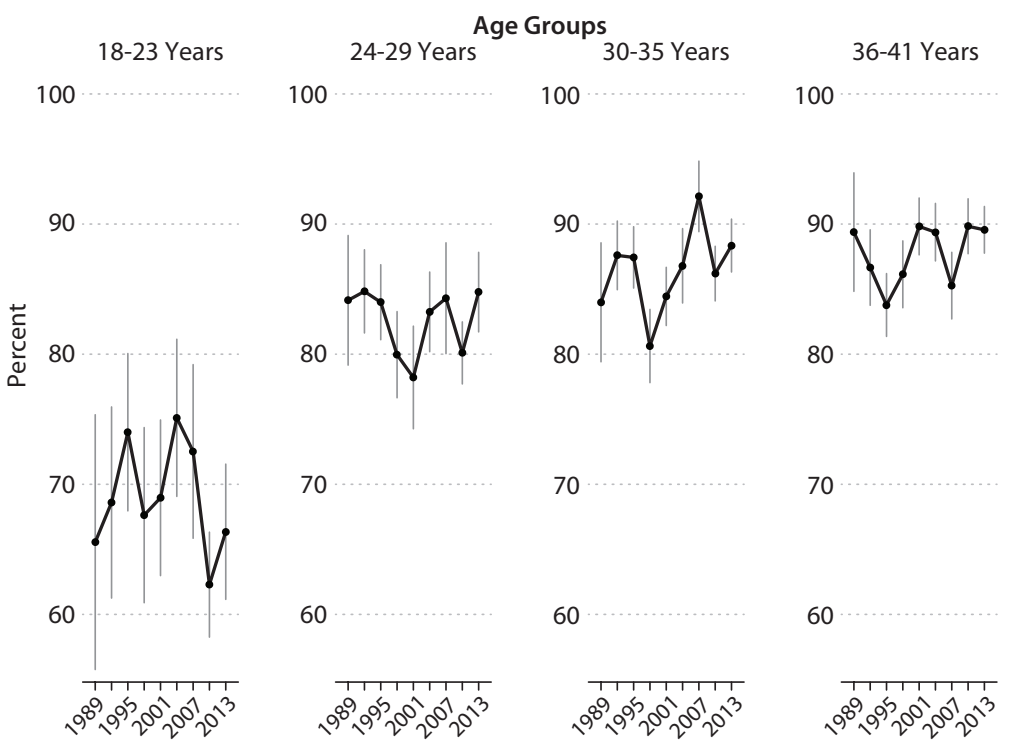

NOTE: Vertical bars represent 95 percent confidence intervals for the means of the groups. SOURCE: SCF.

Figure 5

Ownership of Residential Real Estate

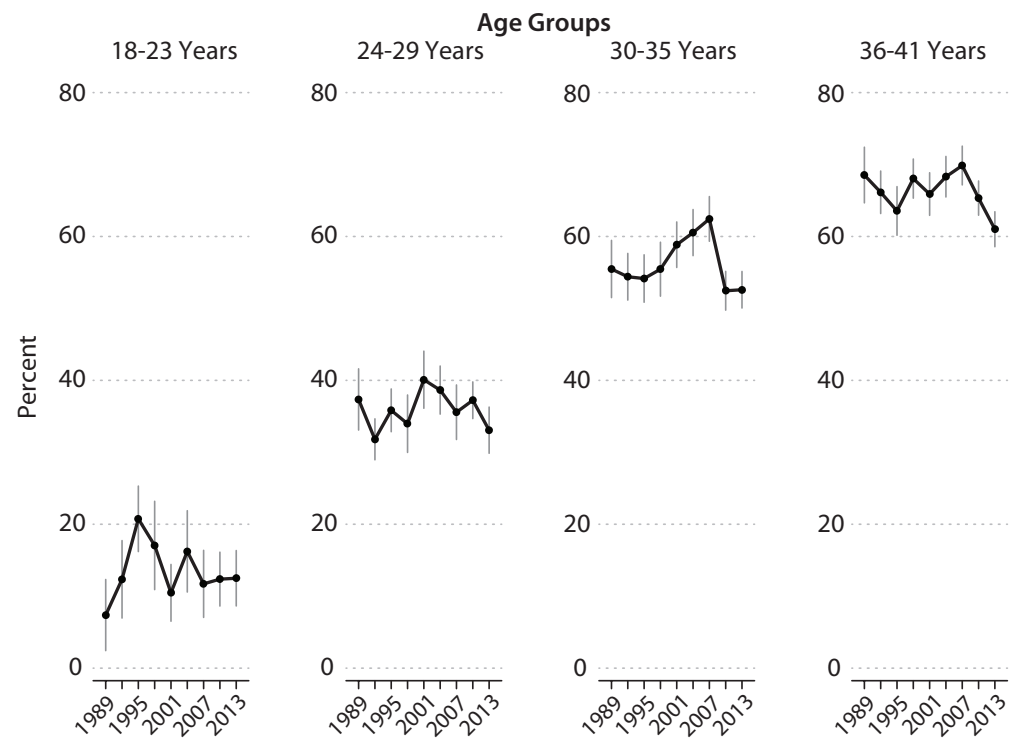

NOTE: Vertical bars represent 95 percent confidence intervals for the means of the groups. SOURCE: SCF. 


\section{Figure 6}

\section{Ownership of Retirement Accounts}

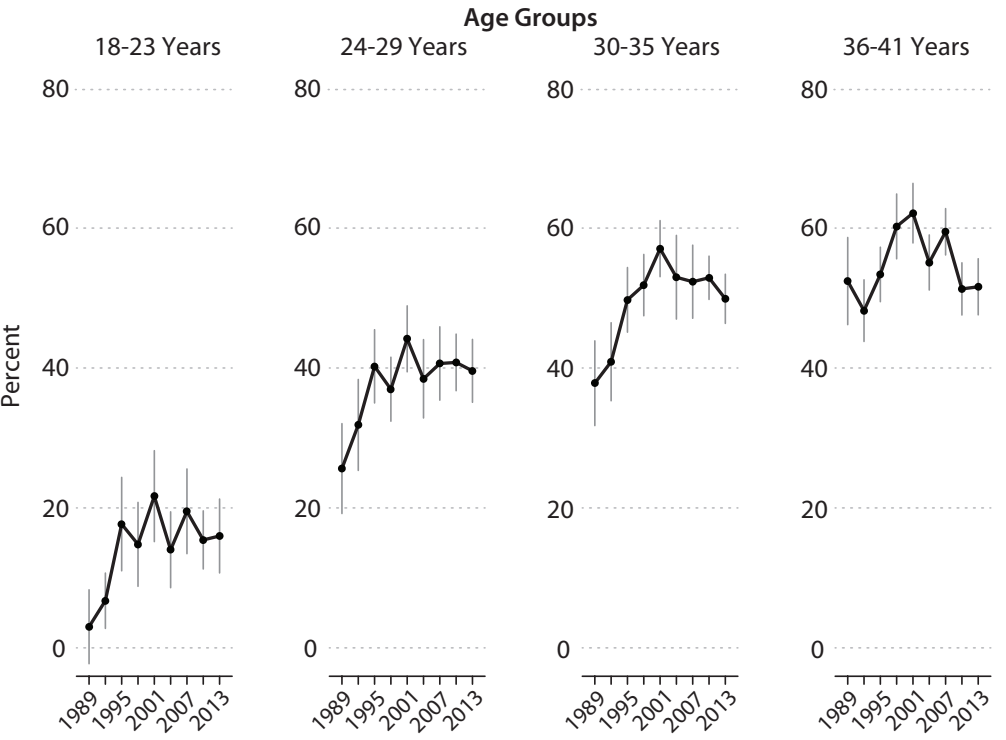

NOTE: Vertical bars represent 95 percent confidence intervals for the means of the groups. SOURCE: SCF.

Figure 7

\section{Ownership of Bonds, Stocks, and Mutual Funds}

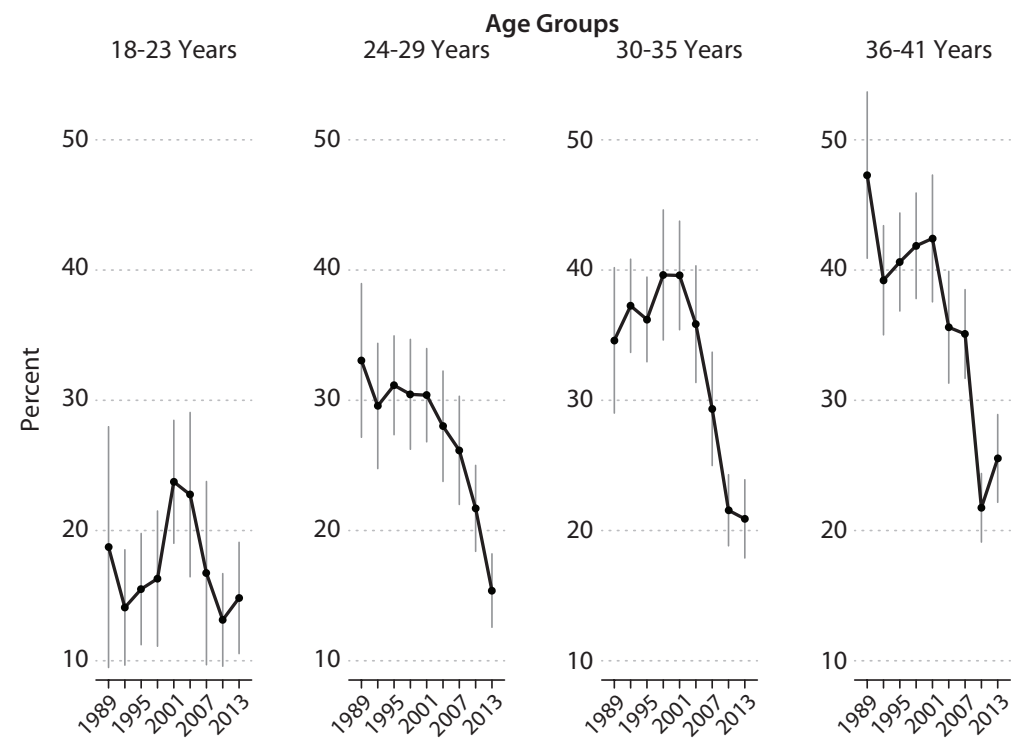

NOTE: Vertical bars represent 95 percent confidence intervals for the means of the groups.

SOURCE: SCF. 


\section{Merry and Thomas}

\section{Figure 8}

\section{Ownership of Business Equity and Nonresidential Real Estate}

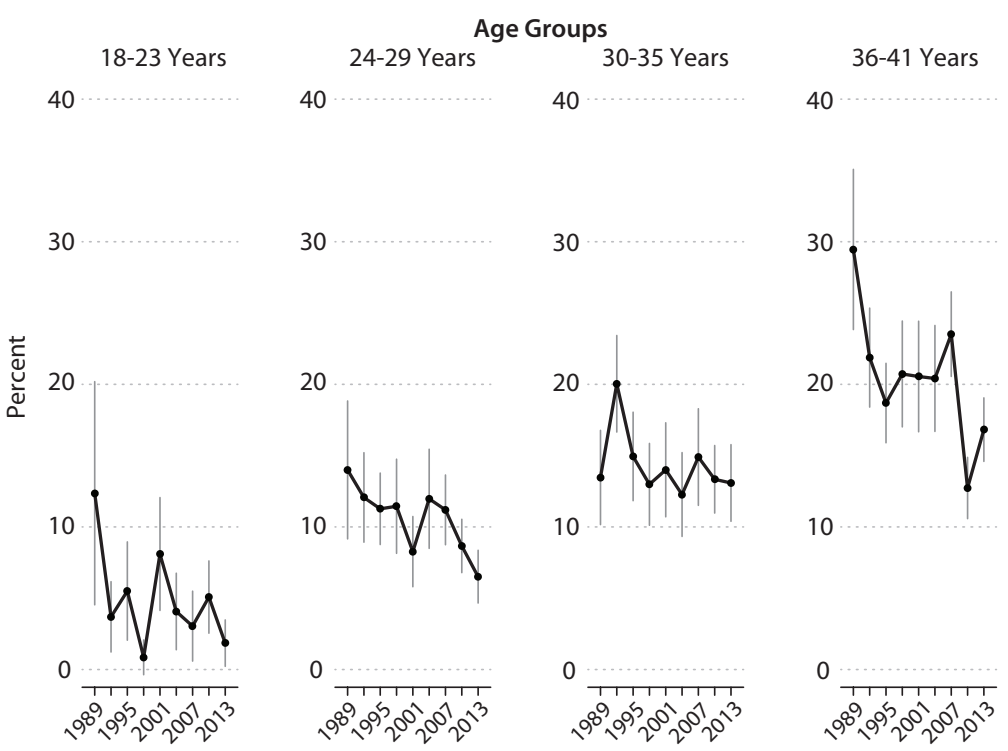

NOTE: Vertical bars represent 95 percent confidence intervals for the means of the groups. SOURCE: SCF.

Figure 9

Ownership of Other Assets

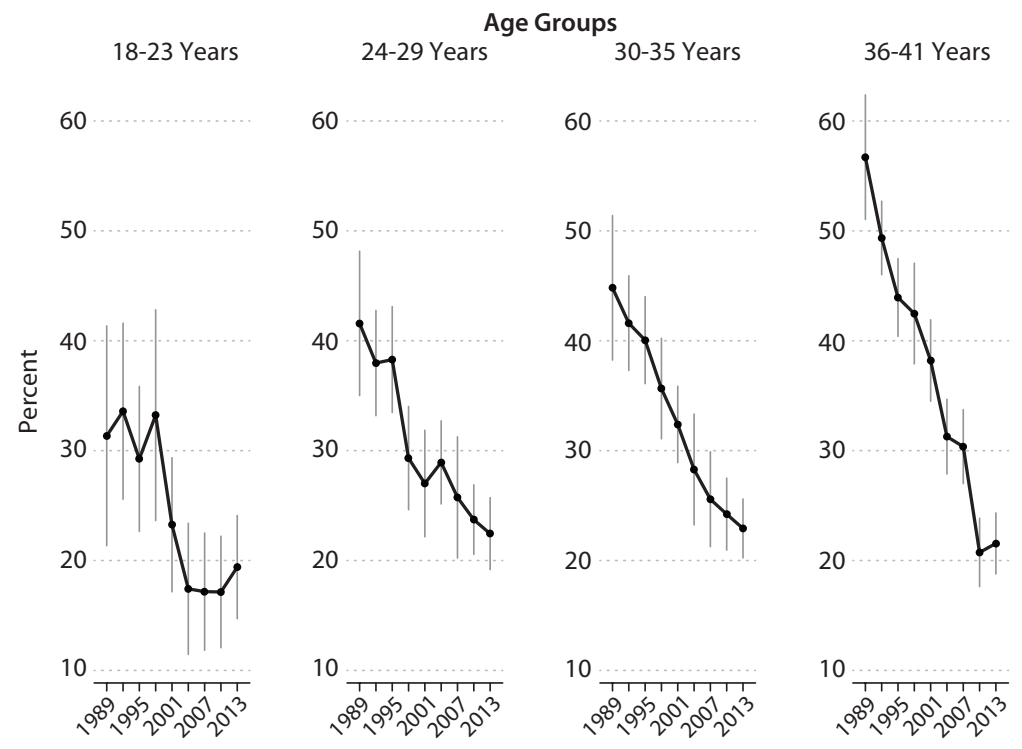

NOTE: Vertical bars represent 95 percent confidence intervals for the means of the groups. SOURCE: SCF. 
Great Recession appears to have been felt by these groups, as evidenced by the drop in their ownership rates after 2007.

As with transaction accounts, ownership of retirement accounts has trended up over time for the younger age groups (Figure 6). Ownership rates for all age groups peaked in 2001, just after the rise in stock prices of the late 1990s. Ownership rates for the two older age groups have trended down somewhat since then.

The remaining three asset types are less widely held among young households, and their ownership rates have also fallen over time. Ownership rates for bonds, stocks, and mutual funds have dropped substantially, particularly for the older age groups (Figure 7). As with retirement accounts, much of this decline has occurred since 2001. Although the patterns over time are not as pronounced as with some other asset categories, ownership rates of business and nonresidential real estate have also trended lower over time (Figure 8). Ownership of other assets has dropped steadily over time (Figure 9), driven primarily by the decline in ownership of life insurance (not shown). Ownership rates for the broad other financial and other nonfinancial components of this category have declined over time as well.

\section{Differences in Asset Holdings Across Households}

Portfolio composition can vary substantially across different demographic groups. Education and race are two household characteristics often considered in discussions of wealth holding. To briefly explore how asset holdings may differ across households in the SCF based on these characteristics, we focus on the young households whose head of household is between 36 and 41 years of age. We focus on this group to possibly avoid some of the complications of differences in the timing of household formation across different segments of the population since many adults have formed independent households by this age. This age group also provides a snapshot of overall asset ownership patterns just as many of these households are entering their middle years of work and raising families.

Figure 10 provides an overall look at the mean rate of ownership of the seven different asset types for households in the 36- to 41-year age group whose head of household has a college degree (the blue outer line) and for those households whose head does not have a college degree (the red inner line). Households whose head has a college degree have higher rates of ownership of all asset types relative to those households whose head does not have a degree. ${ }^{10}$ The differences in ownership rates are smaller for the vehicles and transaction accounts and CDs categories (4 percentage points and 14 percentage points, respectively) but larger for residential real estate (26 percentage points), the third most commonly held asset for households in this age group.

Large differences in ownership rates are particularly evident for the financial assets in the retirement accounts category (40 percentage points) and the bonds, stocks, and mutual funds category (34 percentage points). As noted earlier, both of these asset categories can contain some of the same types of underlying securities, but retirement accounts have a number of distinguishing institutional features that can set them apart. Some of these features-particularly automatic enrollment and payroll deductions-may be important for spurring asset ownership. That said, some employers do not offer retirement plans, and Copeland (2013) finds 


\section{Figure 10}

\section{Asset Ownership for Young Households Ages 36-41 in 2013 by Education of the Head of Household}

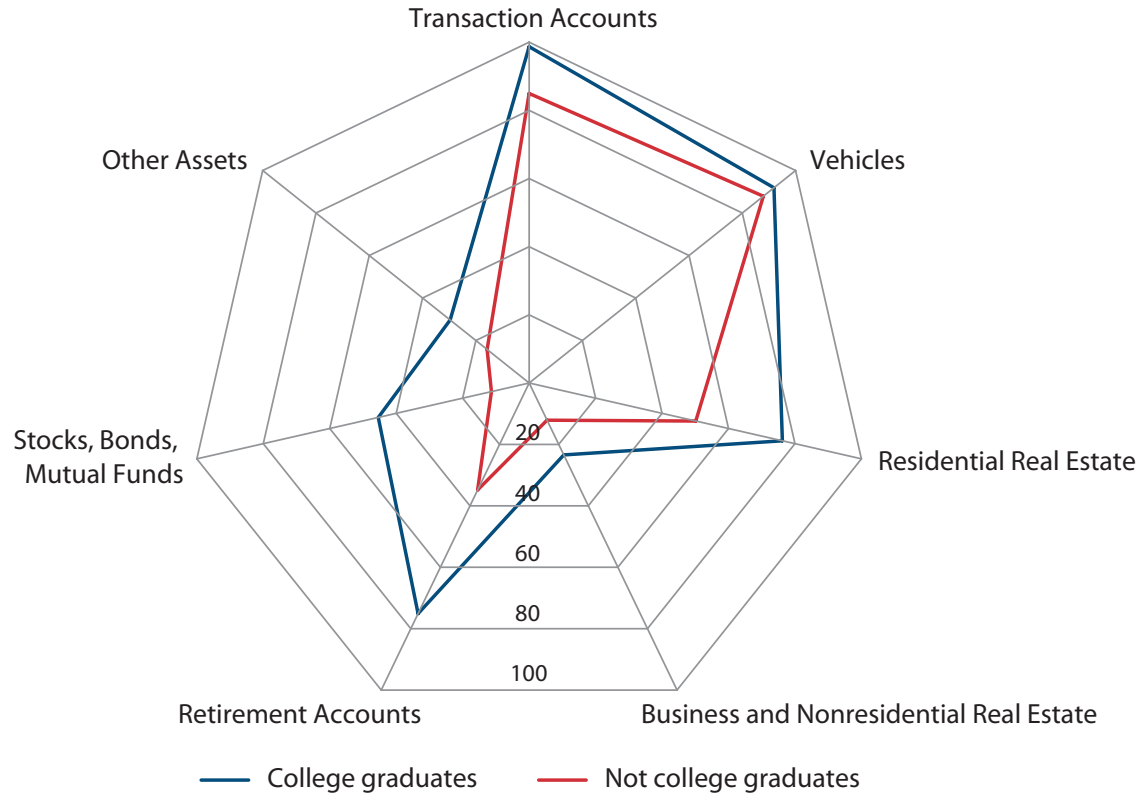

NOTE: The center is at 0 . Values reflect percentage points.

SOURCE: SCF.

that minority workers and those with lower levels of education are less likely to work for employers or unions that sponsor a plan for any of their employees. Thus, part of the observed difference in the ownership of retirement accounts may be attributable to differences in access to employer-sponsored plans.

Figure 11 shows a similar comparison for households in the 36- to 41-year age group but focuses on differences by race/ethnicity. The public version of the SCF data provides sufficient detail to identify black, Hispanic, and white non-Hispanic households separately, but respondents who self-identify as Asian, American Indian, Pacific Islander, and other races are grouped together in a single category. ${ }^{11}$ Because of the relatively small number of observations for minorities in this age group, we group households into two groups for this comparison. One group includes black and Hispanic households, as these groups have relatively similar ownership rates for several asset types. The other group includes white non-Hispanic households and the other minority households pooled in the public data, as the asset ownership patterns of this other group appear more similar to the ownership patterns for white non-Hispanic households than to those for black and Hispanic households.

The differences in ownership patterns based on race/ethnicity show a pattern very similar to the differences across educational status. Households whose head is white non-Hispanic or 


\section{Figure 11}

\section{Asset Ownership for Young Households Ages 36-41 in 2013 by Race/Ethnicity of the Head of Household}

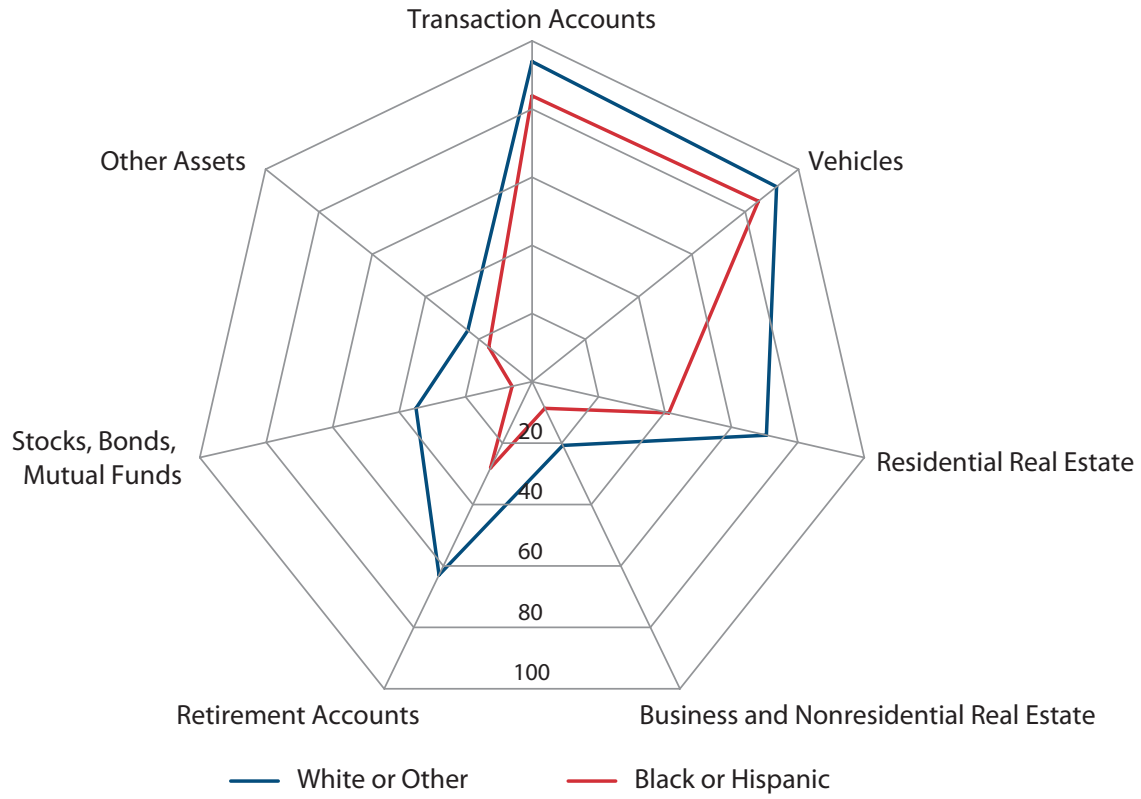

NOTE: The center is at 0 . Values reflect percentage points.

SOURCE: SCF.

one of the other minority groups (the blue outer line) have higher ownership rates of all asset types relative to black and Hispanic households (the red inner line). ${ }^{12}$ As with education, the largest differences in ownership rates are in the categories for retirement accounts (35 percentage points), residential real estate (29 percentage points), and bonds, stocks, and mutual funds (29 percentage points). Differences in ownership rates for transaction accounts and CDs and vehicles are smaller (10 percentage points and 7 percentage points, respectively).

Racial differences in wealth and asset ownership are well documented in the existing literature; this previous work suggests some possible reasons for the sizable differences in the probability of ownership of assets. For example, Menchik and Jianakoplos (1997) note that white households are more likely to have either received or expect to receive some type of inheritance, which may increase their chances of owning any given asset type. Houses are a noteworthy example, as inheritances and other types of wealth transfers are commonly used for down payments on real estate purchases. Also, Caskey (1997) finds that some black and Hispanic households do not save because of social network pressure to share any such savings.

Basic comparisons of differences in asset ownership rates such as those included here for education and race/ethnicity exclude many other important factors that may be helpful in explaining the variation in household portfolios. These factors include differences in income; 


\section{Merry and Thomas}

geographic location, which can affect the cost and availability of transportation and housing; and participation in government programs, which can include asset limits as a condition of eligibility. However, these basic comparisons suggest the need for additional attention to the portfolio choice challenges and opportunities faced by households across the income and wealth distributions. The asset classes with the greatest differences in ownership rates in these comparisons (i.e., retirement accounts, residential real estate, and bonds, stocks, and mutual funds) are also the categories with the potential for significant long-run appreciation, which can contribute to household economic security over time. ${ }^{13}$

\section{CONCLUSION}

The multiple waves of the SCF over time provide the opportunity to explore trends and patterns in the asset holdings of younger households in the years leading up to the Great Recession and the period immediately after the downturn. This historical experience can enrich our understanding of how young households use the range of available asset choices as they seek to build wealth and maintain financial stability in the early stages of adulthood.

Ownership of transaction accounts and CDs and vehicles is relatively high for young households across the 1989-2013 period, and ownership of transaction accounts appears to have risen somewhat over this period.

Ownership rates for residential real estate have a distinct life cycle pattern in the young adult years; rates start low when households first reach adulthood and rise substantially by the time they reach their late 30s and early 40s. Ownership patterns for residential real estate have been generally consistent from 1989 to 2013, although there are some indications of the effects of the housing boom and Great Recession on ownership rates for this asset category, particularly for households in their 30 s and early 40 s.

Ownership of retirement accounts also increases substantially over the early adult years. While ownership of these accounts has increased for young households between 1989 and 2013, ownership rates have trended down somewhat since 2001.

Ownership of bonds, stocks, and mutual funds outside retirement accounts also increases with age, although the share of households that own this category of assets is lower than for residential real estate and retirement accounts and has fallen markedly in recent years. Business equity and nonresidential real estate holdings increase with age as well, although it is the least widely held asset category for young households and ownership has also declined somewhat over the 1989-2013 period. Ownership of other assets, which include both financial and nonfinancial assets not included in the other categories, has also fallen steadily over this period.

Consistent with the existing literature on the impact of demographic factors on asset holdings, we find that race/ethnicity and education matter for holdings of all asset types. Black and Hispanic households and those without a college degree are less likely to own all of the asset types. For young households in the 36- to 41-year age group who have generally formed independent households and are entering the middle years of work and raising families, the largest differences in ownership rates by education and race are for retirement accounts, residential real estate, and bonds, stocks, and mutual funds. 
Young households typically have long time horizons to accumulate wealth. Their ability to (i) invest in assets likely to appreciate and (ii) weather short-term shocks can yield significant benefits both now and in the future as they age. Many young households faced financial shocks during the Great Recession that may have necessitated the liquidation of assets or impaired their ability to save and invest for the future. Additional research on the patterns of asset holding over time may improve our understanding of factors affecting asset acquisition before and after the recession. The recession was also a reminder of the importance of examining which asset ownership strategies are also sustainable, particularly for young households and others who may be just starting to build wealth. 


\section{Merry and Thomas}

\section{NOTES}

1 Our analysis is built on the asset categories defined in the SCF Summary Extract Public Data files. These data include variables used in Federal Reserve Bulletin articles on the SCF. While the SCF is typically conducted as a cross-sectional survey, panel data were collected between 1983 and 1989 and between 2007 and 2009, although the panels are not used in this study. More information on the SCF, including codebooks and other documentation, is available at http://www.federalreserve.gov/econresdata/scf/scfindex.htm.

2 For example, see Emmons and Noeth (2013) and Herbert, McCue, and Sanchez-Moyano (2013).

3 The owner of an asset often has positive net equity in that asset, but not always. It has been common recently for many homeowners to have an outstanding mortgage balance greater than the market value of the house.

4 Although the SCF includes data on defined benefit pensions, such plans are not included in this measure.

5 In Table 1 of his article, Kennickell includes an inventory of all the income, debt, and asset categories measured in the SCF, as well as some categories that are only partially measured or not measured at all.

6 All estimates of asset ownership rates presented in this section are computed using the SCF weights.

7 The SCF is a household survey, and the focus is on the "primary economic unit" consisting of a single individual or a couple together with other members of the household who are financially interdependent with that individual or couple. When a single individual is economically dominant in the household, that person is defined as the head of the household. For the purpose of organizing the data for couples, the SCF defines the household head as the male in a mixed-sex couple or the older individual in a same-sex couple.

8 The vertical bars in the graphs represent the 95 percent confidence interval for the mean ownership rate for each group. The authors appreciate Karen Pence's sharing of code to compute standard errors accounting for both sampling and imputation variance in the SCF.

9 Sample sizes for the younger age groups are smaller than for older age groups across all waves of the SCF. Caution is warranted in interpreting the asset holding rates for those 18 to 23 years of age and those 24 to 29 years of age because the smaller samples imply more sampling variability in the estimates of the ownership rates for these younger age groups.

${ }^{10}$ The difference in vehicle ownership is statistically significant at the 5 percent level. All other differences between asset ownership rates for these two groups based on the education of the head of household in 2013 are statistically significant at the 1 percent level.

${ }^{11}$ In recent waves of the SCF, respondents have been able to self-identify as more than one race or ethnicity but are asked to respond first with the category that best describes their race. For simplicity, we classify the household's race based on the first response.

${ }^{12}$ All differences between asset ownership rates for these groups based on the race or ethnicity of the household head in 2013 are statistically significant at the 1 percent level.

${ }^{13}$ See Wolff (2012) for estimates of rates of return for several broad asset types similar to those used in this article.

\section{REFERENCES}

Bricker, Jesse; Kennickell, Arthur B.; Moore, Kevin B. and Sabelhaus, John. “Changes in U.S. Family Finances from 2007 to 2010: Evidence from the Survey of Consumer Finances." Federal Reserve Bulletin, June 2012, 98(2), pp. 1-80; http://www.federalreserve.gov/pubs/bulletin/2012/pdf/scf12.pdf.

Caskey, John P. "Beyond Cash-and-Carry: Financial Savings, Financial Services, and Low-Income Households in Two Communities." Washington, DC: Consumer Federation of America, 1997.

Copeland, Craig. "Employment-Based Retirement Plan Participation: Geographic Differences and Trends, 2012." EBRI Issue Brief, No. 378, Employee Benefit Research Institute, November 2013; http://www.ebri.org/pdf/briefspdf/EBRI_IB_11-2012_No378_RetParticip.pdf.

Dettling, Lisa J. and Hsu, Janne W. "The State of Young Adults' Balance Sheets: Evidence from the Survey of Consumer Finances." Federal Reserve Bank of St. Louis Review, Fourth Quarter 2014, 96(4), pp. 305-30. 
Emmons, William R. and Noeth, Bryan J. "Why Did Young Families Lose So Much Wealth During the Crisis? The Role of Homeownership." Federal Reserve Bank of St. Louis Review, January/February 2013, 95(1), pp. 1-26; http://research.stlouisfed.org/publications/review/13/01/Emmons.pdf.

Gouskova, Elena; Juster, F. Thomas and Stafford, Frank, P. “Trends and Turbulence: Allocations and Dynamics of American Family Portfolios, 1984-2001," in Edward N. Wolff, ed., International Perspectives on Household Wealth. Northampton, MA: Edward Elgar, 2006, pp. 365-93.

Herbert, Christopher E.; McCue, Daniel T. and Sanchez-Moyano, Rocio. "Is Homeownership Still an Effective Means of Building Wealth for Low-Income and Minority Households? (Was It Ever?)." Working Paper No. HBTL-06, Joint Center for Housing Studies, Harvard University, September 2013; http://www.jchs.harvard.edu/sites/jchs.harvard.edu/files/hbtl-06.pdf.

Hogarth, Jeanne M.; Anguelov, Christoslav E. and Lee, Jinhook. "Who Has a Bank Account? Exploring Changes over Time, 1989-2001." Journal of Family and Economic Issues, Spring 2005, 26(1), pp. 7-30.

Holden, Sarah and Bass, Steven. "The IRA Investor Profile: Traditional IRA Investors' Activity, 2007-2012." ICI Research Report, Investment Company Institute, March 2014; http://www.ici.org/pdf/rpt_14_ira_traditional.pdf.

Kennickell, Arthur B. "Ponds and Streams: Wealth and Income in the U.S., 1989 to 2007." Finance and Economics Discussion Series 2009-13, Federal Reserve Board, January 2009;

http://www.federalreserve.gov/pubs/feds/2009/200913/200913pap.pdf.

Mannering, Fred; Winston, Clifford and Starkey, William. "An Exploratory Analysis of Automobile Leasing by U.S. Households." Journal of Urban Economics, July 2002, 52(1), pp. 154-76.

Menchik, Paul L. and Jianakoplos, Nancy A. "Black-White Wealth Inequality: Is Inheritance the Reason?" Economic Inquiry, April 1997, 35(2), pp. 428-42.

Pendall, Rolf; Hayes, Christopher; George, Arthur; McDade, Zach; Dawkins, Casey; Jeon, Jae Sik; Knaap, Eli; Blumenberg, Evelyn; Pierce, Gregory and Smart, Michael. "Driving to Opportunity: Understanding the Links among Transportation Access, Residential Outcomes, and Economic Opportunity for Housing Voucher Recipients." Washington, DC: Urban Institute, 2014; http://www.urban.org/uploadedpdf/413078-driving-to-opportunity.pdf.

Wolff, Edward N. "Changes in Household Wealth in the 1980s and 1990s in the United States," in Edward N. Wolff, ed., International Perspectives on Household Wealth. Northampton, MA: Edward Elgar, 2006, pp. 107-50.

Wolff, Edward N. "The Asset Price Meltdown and the Wealth of the Middle Class." NBER Working Paper No. 18559, National Bureau of Economic Research, November 2012; http://www.nber.org/papers/w18559.pdf. 
